\title{
ANALISA KEBERLANJUTAN BMT DALAM PADEMI COVID 19 BERBASIS BISNIS MODEL DAN PEMILIHAN PELAYANAN ANGGOTA PEMBIAYAAN (SELECTIVE LENDING)
}

Lukmanul Hakim ${ }^{*}$, Annisa Brilyanda Putri Aureli ${ }^{2}$, Zulkifli Adam ${ }^{3}$, Irina Ayu Sagita ${ }^{4}$, Feni Nenden Anisah ${ }^{4}$, Citra Tri Agustine Nusantara ${ }^{5}$, Atu Aisyah Amin ${ }^{6}$

${ }^{123456}$ Fakultas Ekonomi dan Bisnis Islam, Universitas Suryakancana *Corresponding Author e-mail: lukmanbmtim@gmail.com

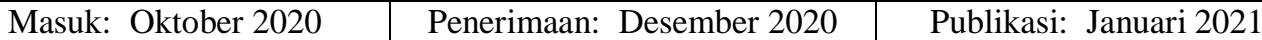

\begin{abstract}
ABSTRAK
Dampak dari pandemi covid-19 menghantam semua sektor kehidupan, termasuk kepada lembaga keuangan mikro syariah Baitul Maal wat Tamwil (BMT) sebagai lembaga keuangan yang memberikan pelayanan keuangan kepada pengusaha mikro, kecil dan menengah (UMKM). Kebijakan pelaksanaan pembatasan aktivitas sosial untuk mencegah penyebaran virus corona mengakibatkan penurunan pendapatan usaha para pengusaha mikro, kecil dan menengah bahkan sebagian terpaksa menutup usahanya yang berdampak kemampuan pembayaran para pengusaha mikro,kecil dan menengah kepada lembaga keuangan BMT terhambat. Tujuan penelitian ini untuk menganalisa dampak pademi covid 19 untuk keberlanjutan BMT dengan basis Bisnis Model dan pemilihan anggota pembiayaan (selective lending). Metode penelitian ini menggunakan metode purposive sampling anggota mitra Gakopsyah BMT Jawa Barat. Teknik analisis data yang digunakan dalam penelitian ini adalah analisis regresi liner berganda. Hasil penelitan menunjukan bahwa bisnis model dan pemilihan anggota pembiayaan (selective lending) tidak berpengaruh positif kepada keberlanjutan BMT.
\end{abstract}

Kata Kunci : Keberlanjutan BMT, Bisnis Model, Anggota dan Pembiayaan.

\begin{abstract}
The impact of the Covid-19 pandemic has endangered all sectors of life, including the Islamic microfinance institution Baitul Maal wat Tamwil (BMT) as a financial institution that provides financial services to micro, small and medium entrepreneurs (UMKM). The policy of limiting social activities to prevent the spread of the corona virus has resulted in a decrease in the business income of micro, small and medium entrepreneurs and even some are forced to close their businesses which has an impact on the ability to pay micro, small and medium entrepreneurs to BMT financial institutions. The purpose of this study is to analyze the impact of pandemic covid-19 for the sustainability of BMT on the basis of a Business Model and selective lending. This research method uses purposive sampling method of partner members of Gakopsyah BMT West Java. The tool used in this research is multiple linear regression analysis. The research results show that the business model and the selection of financing members (selective lending) do not have a positive effect on the sustainability of BMT.
\end{abstract}

Keywords: $\quad$ Sustainability BMT, Business Model, Members and Selective Lending. 


\section{A. PENDAHULUAN}

Dunia dikejutkan dengan pademi wabah virus covid 19, yang melumpuhkan hampir semua lini kehidupan manusia, virus ini menciptakan efek domino yang merugikan berbagaisektor, selain kepada kesehatan dampaknya juga sangat terasa kepada sektor ekonomi dengan pembatasan aktivitas masyarakat yang berpengaruh pada aktivitas usaha yang berimbas kepada perekonomian. Laporan Badan Pusat Statistik (BPS) di bulan agustus 2020 menyebutkan pertembuhan ekonomi Indonesia pada kuartal II minus 5,32 \% yang sebelumnya pada kuartal I tumbuh sebesar $2,97 \%$, turun jauh dari pertembuhan $5.02 \%$ pada periode yang sama pada tahun 2019. Bahkan seperti apa yang diproyeksikan oleh Menteri Keuangan Sri Mulyani Indrawati, perekonomian Indonesia pada kuartal III akan mengalami kontraksi minus 2,9\% hingga $1.1 \%$. dan ini mengidentifikasikan bahwa Indonesia akan masuk pada jurang resesi ekonom.

Dampak tersebut juga terasa di lembaga keuangan mikro syariah yaitu Baitul Maal wat Tamwil (BMT) sebagai lembaga keuangan mikro dengan prinsip syariah (LMKS) yang berbadan hukum koperasi simpan pinjam dan pembiayaan syariah berbasis swadaya masyarakat adalah lembaga yang memberikan pelayanan keuangan pada wilayah mikro, yang melayani masyarakat menengah bawah dan memperbaiki kemampuan dasar yang dibutuhkan oleh masyarakat untuk mengembangkan bisnis mereka seperti sumber daya, pendidikan dan social network (Kholis, 2009).

Usaha Mikro Kecil Menengah (UMKM) sebagai target utama pelayanan BMT mengalami dampak yang sangat besar, karena mereka bergantung kepada likuiditas harian yang ini menjadi penopang arus kas nya BMT (Hawariyuni dan Skati, 2020), ditambah masalah lain yang berdampak kepada BMT adalah unintended consequences dari pidato Presiden Joko Widodo ketika mengumumkan keringan kredit bagi masyarakat yang perekonomiannya terdampak pademi Covid 19 ada selasa (24/3) banyak anggota BMT yang memiliki arus kas yang baik, meminta untuk menunda pembayaran angsuran.

Copyright @ 2019, El-Ecosy: Jurnal Ekonomi dan Keuangan Islam

Fakultas Ekonomi dan Bisnis Islam Universitas Suryakancana 
Walaupun OJK mengeluarkan POJK No.11/POJK.03/2020 yang mengatur restrukturisasi kredit, aturan itu ditujukan bagi perbankan dan leasing bukan BMT. (Republika.co.id/dampak- covid19), termasuk bermunculan di berbagai daerah adanya surat dari kepala desa atau aparat lokal terkait pelarangan penagihan angsuran atau cicilan ke warga mereka dan disertai penutupan beberapa tempat seperti pasar. Akibatnya repayment rate mengalami penurunan tajam. Selain itu, penerapan physical distancing berdampak sulitnya BMT mengumpulkan anggota. Khususnya, BMT yang menerapkan pembiayaan kelompok. Tanpa pertemuan kelompok angsuranpun "libur".

Dari sisi keuangan secara umum, sudah terjadi penarikan tabungan oleh anggota karena kebutuhan selama pandemi dan konsumsi yang meningkat untuk menjaga imunitas tubuh. Diperparah pekerja informal, baruh pabrik dan UMKM yang tidak bisa beraktivitas lagi secara normal. Informasi yang diterima, dalam sebulan ada BMT yang mengalami penarikan tabungan sampai Rp 1 miliar. Angsuran pembiayaan mulai tersendat, khususnya UMKM.

Ditengah sulitnya perekonomian saat ini, Semua upaya difokuskan agar organisasi dapat bertahan hidup dalam kondisi pasar unstable and dangerous. Selain itu penelitian ini untuk mencari metode bagaimana keberadaan BMT sebegai lembaga keuangan mikro syariah dapat terus berlanjut atau lestari dan terus berperan memberikan alternatif pembiayaan mikro untuk masyarakat.

Dari sudut pandang bisnis, keberlanjutan (sustainability) adalah tentang bagaimana mengurangi biaya sekarang maupun biaya yang mungkin timbul dimasa mendatang, dalam bentuk apapun sehingga dapat menfasilitasi profitabilitas, daya saing dan umur usaha (Widiyanto, 2020). Penetuan bisnis model menjadi kebutuhan yang mutlak keberhasilannya, yaitu semakin sebuah organisasi memahami tentang bisnis modelnya. Maka keberlanjutan organisasi tidak akan lepas dari peran bisnis model yang dikembangkannya.

Bisnis model adalah gambaran dasar bagaimana sebuah organisasi membuat, mendeliver dan mengungkap value yang ada. Bisnis model bersifat seperti blueprint untuk strategi yang akan di implementasikan ke seluruh

Copyright @ 2019 , El-Ecosy: Jurnal Ekonomi dan Keuangan Islam

Fakultas Ekonomi dan Bisnis Islam Universitas Suryakancana 
organisasi, proses dan sistem. Bisnis model dibutuhkan sebagai dasar agar organisasi dapat layak dan terus berdiri. Untuk itu bisnis model seperti apa yang pada pademi covid 19 ini dapat dikembangkan bisa berdampak positif yang signifikan bagi ekonomi dan keberlangsungan BMT.

Bisnis utama lembaga keuangan adalah penyaluran pembiayan yang berkualitas, pemilihan anggota pembiayaan menjadi fokus yang dominan. Dalam proses pemilihan anggota pembiayaan (selective lending) sangat penting karena dapat membantu mempertahankan atau menjaga profitabilitas lembaga, dapat membantu karyawan agar tetap produktif, sehingga organisasi dapat bertahan dalam jangka waktu yang cukup lama. Dalam pemilihan anggota pembiayaan bukan hal yang mudah karena salah menetukan pilihan bisa mengganggu kegiatan operasional usaha, keuangan dan keberlanjutan lembaga.

Dimasa pademi covid 19 ini, yang telah menciptakan krisis, memaksa semua organisasi tidak terkecuali lembaga keuangan mikro syariah Baitul maal wat tamwil (BMT) untuk dapat bertahan dan berlanjut keberadaannya. Menurut Aziz (2006) lembaga keuang mikro syariah BMT tidak memiliki lembaga penjamin likuiditas dan hanya server organisasi mikro dengan dana kecil merupakan permasalah yang sering dihadapi oleh BMT. Akibatnya kebutuhan modal untuk usaha mikro tidak dapat sepenuhnya terpenuhi yang berarti usaha mikro masih menghadapi kesulitan dalam mengembangkan sektor bisnisnya. Kondisi ini juga akan mempengaruhi profitabilitas dan keberlanjutan BMT (Widiyanto, 2020).

BMT sebagai lembaga keuangan mikro syariah yang jati dirinya paling pokok adalah identitas keIslamannya, untuk membantu pengentaasan kemiskinan dan membebaskan masyarakat dari praktik ribawi diharapkan dapat terus berlanjut keberadaannya (Widiyanto, 2020). Sangat penting untuk mempertahankan keberlanjutan Baitul Maal wat Tamwil (BMT) agar dapat mempertahankan keberadaannya pada pasca pademi covid 19 ini, maka penelitian ini bertujuan untuk mengkaji apakah ada pengaruh bisnis model dan pemilihan anggota yang dilayani (selective lending) terhadap keberlanjutan BMT.

Copyright $(0)$ 2019, El-Ecosy: Jurnal Ekonomi dan Keuangan Islam

Fakultas Ekonomi dan Bisnis Islam Universitas Suryakancana 


\section{B. METODE PENELITIAN}

Penelitian ini menggunakan sampel BMT anggota Gakopsyah BMT Jawa Barat, dengan jumlah reponden yang bersedia mengisi kuesioner sebanyak 14 dari 23 anggota mitra Gakopsyah BMT Jawa Barat yang aktif pada tahun 2020 Penelitian ini menggunakan analisa regresi berganda dengan persamaan sebagai berikiut sebagai berikut :

$$
\mathbf{Y}=\mathbf{a}+\mathbf{b}_{1} \mathbf{X}_{1}+\mathbf{b}_{2} \mathbf{X}_{2}+\mathbf{e}
$$

\section{Dimana :}

$$
\begin{array}{ll}
\mathrm{Y} & =\text { Sustainability BMT } \\
\mathrm{a} & =\text { Konstanta } \\
\mathrm{X}_{1} & =\text { Model Bisnis } \\
\mathrm{X}_{2} & =\text { Pemlihan Anggota Pembiayaan (Selective Lending) } \\
\mathrm{e} & =\text { Error }
\end{array}
$$

Pengujian dengan regresi tersebut didahului dengan uji normalitas, heteroskedasitas, multikonlinieritas dan uji autokorelasi yang hasilnya menunjukan bahwa pemenuhan asumsi sebagaiamana yang dipersyaratakan pengujian persamaan regresi liner berganda. Sebelum pengujian asumsi di atas juga telah dilakukan dengan uji instrumen yaitu uji validitas dan relibilitas.

\section{PEMBAHASAN DAN HASIL PENELITIAN}

\section{Keberlanjutan (Sustainability) BMT}

Belum ada satu pun pihak yang dapat memprediksi dengan pasti berakhirnya pademi covid 19 ini, memaksa manajemen BMT untuk sadar akan perluanya pengelolaan sustainability yang bertujuan untuk kinerja sosial, lingkungan dan ekonomi secara bersamaan. Sustainability adalah ketahanan jangka panjang suatu organisasi/lembaga dalam menghadapi kesempatan dan tantangan perekonomian yang uncertain. Casarejos et al (2017), menyatakan bahwa sustainability merupakan sebuah tindakan yang harus diintergasikan dan diproritaskan dalam pengaturan lembaga. Sustainability tersebut dimaksudkan untuk mencapai tujuan dalam mengatasi kebutuhan masyarakat yang ingin bertransisi menjadi masyarakat yang lebih tangguh.

\footnotetext{
Copyright (C) 2019, El-Ecosy: Jurnal Ekonomi dan Keuangan Islam

Fakultas Ekonomi dan Bisnis Islam Universitas Suryakancana 
Sustainability lembaga keuangan mikro itu sendiri berkaitan dengan kemampuan LKM untuk memberikan manfaat sosial ekonomi yang nyata guna meningkatkan nilai mata pencaharian masyarakat luas (Bhanot dan Bapat, 2015). Dari pemaparan diatas dapat disimpulkan bahwa BMT dapat terus berlanjut atau lestari adalah ketika BMT dapat terus memberikan kontribusi lebih untuk memperbaiki kehidupan masyarakat luas.

Menurut Szekely (2005) salah satu pendekatan yang paling sering digunakan untuk mengukur sustainability organisasi adalah dengan pendekatan triple botton line. Pendekatan tersebut melibatkan tiga dimesi, yaitu:

a. Lingkungan, mengukur dampak pada sumber daya;

b. Sosial, berhubungan dengan corporate governan, motivasi, insentif, keamanan dan kesehatan, pengembangan sumberdaya manusia, hak asasi manusia dan prilaku etika;

c. Ekonomi mengacu pada pengukuran pemeliharaan atau peningkatan keberhasilan organisasi/lembaga sebagai contoh, teknologi dan inovasi, kolaborasi, manajemen pengatahuan, pembelian, proses dan pelaporan sustainability.

Konsep triple botton line digunakan sebagai landasan prinsipal dalam aplikasi program corporate social responsibility pada organisasi/lembaga (Eikington,1997). Tiga kepentingan yang menjadi satu merupakan garis besar dan tujuan utama tanggung jawab sosial sebuah organisasi/lembaga yaitu: Profit, People dan social. BMT sejak kelahirannya memposisikan sebagai lembaga yang menggabungkan dua fungsi, yaitu: sosial, sebagai rumah harta dan Baitul Maal berperan untuk pengumpulan dan penyaluran dana dana zakat, infak, shodakoh dan wakaf (ZISWAF). Baitul Tamwil, sebagai lembaga yang berperan diposisi pengembangan ekonomi, dengan program dan pembiayaan sesuai akad akad syariah. Kedua fungsi tersebut bertujuan untuk mengangkat taraf hidup masyarakat bawah agar memiliki kesejahtraan yang sama.

Rashidah dan Dean (2013) menjelaskan bahwa lembaga keuangan mikro syariah (BMT) yang beroperasi secara efektif, memiliki sumbangsih yang besar

Copyright @ 2019 , El-Ecosy: Jurnal Ekonomi dan Keuangan Islam

Fakultas Ekonomi dan Bisnis Islam Universitas Suryakancana 
untuk menanggulangi tingkat kemiskinan yang terjadi. Sehingga menjaga sustainability BMT menjadi kepentingan semua pihak agar perannya terus dapat dirasakan oleh masyarakat secara luas. Oleh karena itu faktor-faktor penunjang keberhasilan BMT juga harus diteliti dan dianalisa untuk membantu keberlanjutan dimasa yang akan datang.

\section{Model Bisnis}

Pademi covid 19 ini membuat rencana dan strategi pengembangan organisasi menjadi perlu di kaji kembali, banyak organisasi belum siap dengan begitu cepatnya wabah ini menyebar dihampir 193 negara dengan kasus 37,7 juta yang terjangkit, di Indonesia saja per bulan oktober 337 ribu kasus, dari dampak kesehatan melaju ke dampak ekonomi yang mengakibatkan banyak rencana dan strategi bisnis menjadi tidak relevan lagi. Banyak perusahan dengan bisnis yang sudah besar hari ini diberitakan mengalami kontraksi yang cukup parah dan sebagian mengarah kepada kebangkrutan.

Bisnis merupakan suatu organisasi yang menyediakan barang atau jasa yang bertujuan untuk mendapatkan keuntungan, persaingan bisnis yang semakin ketat, setiap perusahaan selalu di tuntut untuk terus berkembang, dengan pengembangan strategi-strategi yang baru. Namun strategi itu sendiri tidaklah cukup, perusahan harus mempunyai bisnis model yang kuat dan baik serta tepat pada perusahaan yang dimiliknya. Bisnis model yang mampu menggambarkan secara sederhana dan menyeluruh terhadap kondisi suatu perusahaan saat ini berdasarkan segmen konsumen yang dilayani. Value yang ditawarkan, jalur penawaran nilai, hubungan dengan pelanggan aliran pendapatan, aset vital, mitra kerja sama, serta struktur biaya yang dimilik (Rainaldo et al, 2017).

Business model canvas (BMC) memiliki keunggulan dalam analisis model bisnis yaitu mampu mengambarkan secara sederhana dan menyeluruh terhadap kondisi suatu perusahaan saat ini berdasarkan segmen konsumen, value yang ditawarkan, jalur penawaran nilai, hubungan dengan pelanggan, aliran pendapatan, aset vital, mitra kerja sama, serta struktur biaya yang dimiliki

Copyright @ 2019, El-Ecosy: Jurnal Ekonomi dan Keuangan Islam

Fakultas Ekonomi dan Bisnis Islam Universitas Suryakancana 
(Rainaldo et al., 2017). Menurut penelitian yang telah dilakukan oleh Euis et al. (2014), business model canvas (BMC) memiliki sembilan elemen yang penting dalam membantu mengidentifikasikan model bisnis dan membantu untuk mengidentifikasi elemen-elemen yang memerlukan perbaikan untuk membantu keberlangsungan usaha di masa depan. Bisnis model kanvas juga dapat digunakan sebagai alat untuk memberikan usulan rancangan model bisnis yang baru yang akan diterapkan salah satu unit usaha baru.

Menurut Osterwalder and Pigneur (2010), model bisnis menggambarkan dasar pemikiran tentang bagaimana organisasi menciptakan, memberikan, dan menangkap nilai Business Model Canvas untuk mampu memberikan respons yang cepat terhadap keinginan pelanggan dengan memberikan nilai-nilai terbaik yang ada dalam perusahaan. Saat ini perusahaan di tuntut melakukan perubahan yang cepat dan dramatis, termasuk BMT, sebagai lembaga keuangan mikro syariah yang melayani para pengusaha mikro dimasyarakat tentunya ingin terus dapat memberikan pelayanan akses keuangan kepada anggotanya, tetap produktif, dapat mempertahankan profitablitas dan mengelola resiko dengan baik. Pada sisi lain, dalam identifiasi masalah di BMT secara internal dan ekternal, kata Asep Sudrajat, Ketua Pengurus BMT Mardlotilah Sumedang, dalam republika online, selasa 10 Maret 2015, mengeloa BMT tidak mudah sebab awal berdirinya manajemen BMT mandiri, dan yang sering menjadi persoalan adalah kualitas sumber daya insani (SDI).”'Ilmu pengelola BMT akan menetukan keberlangsungannya. Butuh kekuatan ruhiyah, juga rupiah' ujarnya, seperti yang disampakan dalam seminar nasional peran pembiyaaan mikro dalam pemberdayaan ummat (GSENT), Senin, (9/3). Asep mencatat, pada 2013 ada sekitar 4.500 BMT yang beroperasi di Indonesia dengan aset mencapai 8 triliyun. Di Jawa barat sendiri jumlah BMT yang beroperasi mencapai 291 dengan aset 900 miliar. Meski dari sisi teknologi BMT sudah cukup kompetitif, modal dan legalitas membuat BMT berbeda dengan bank. Ketidakcocokan pembiayaan dengan dana kadang memicu persoalan likuiditas BMT. Persoalan legalitas juga membuat BMT harus teliti. BMT sebagai koperasi harus menjalankan sebagai

Copyright $@ 2019$, El-Ecosy: Jurnal Ekonomi dan Keuangan Islam

Fakultas Ekonomi dan Bisnis Islam Universitas Suryakancana

Analisa Keberlanjutan BMT Dalam Pandemi Covid 19 Berbasis Bisni Model dan Pemilihan Pelayanan Anggota Pembiayaan (Selective Lending) 
koperasi. Sebab jika dilanggar dendanya 10 miliar, yang bisa jadi lebih besar dari modalnya BMT sendiri. Selain permasalahan internal yang dapat memicu BMT bangkrut.

Saat ini banyak permasalahan-permasalahan yang di hadapi BMT diantaranya pengelolaan manajemen, sumber daya manusia yang tidak profesional, produk yang tidak inovatif, dan belum mamaksimalkan digital, meskipun begitu banyak BMT masih dapat bertahan walau terdapat kendala internal dan ekternal. Fokus BMT dalam peningkatan kesejahtraan masyarakat menengah kebawah yang masih belum tersentuh oleh perbankan, menjadi alasan mengapa BMT sampai saat ini masih bisa bertahan. BMT juga merupakan harapan dalam pertumbuhan ekonomi Indonesia karena membantu pengusaha kecil dalam pengembangan usahannya.

Sehingga diharapkan ketika BMT dapat melakukan perubahan rencana dan strateginya diluar core businessnya, sebagai lembaga intermediary keuangan dengan menggunakan bisnis model yang kuat dan baik, yang dapat mempertahankan keberlajutan lembaganya. Pada penelitian ini, ingin mengetahui bagaimana perubahan strategi BMT dalam pademi covid 19 ini, dengan menggunakan pedekatan bisnis model yang akan membantu dalam proyeksi usaha dan keberangsungan lembaganya.

\section{Pemilihan Anggota pembiayaan (Selective Lending)}

Baitul Maal wat Tamwil (BMT) sebagai lembaga keuangan mikro dengan prinsif syariah (LMKS) yang berbadan hukum koperasi simpan pinjam dan pembiayaan syariah berbasis swadaya masyarakat. Dalam koperasi keberadaan anggota adalah pemilik yang berkewajiban memberikan kontribusi positif kepada organisasinya. Dan disisi lain anggota berkedudukan sebagai pemakai mempunyai hak memperoleh insentif atau manfaat dari organisasi koperasi. Oleh karena itu anggota koperasi dapat dikatakan memilik dua kedudukan (perannya dalam koperasi). Dengan kedua peran/kedudukan tersebut, anggota koperasi mempunyai kedudukan sentral dalam koperasi sebagai suatu lembaga ekonomi. Anggota

Copyright $(0)$ 2019, El-Ecosy: Jurnal Ekonomi dan Keuangan Islam

Fakultas Ekonomi dan Bisnis Islam Universitas Suryakancana 
sebagai mitra utama memiliki keperluan atau kepentingan dengan organisasi yang dia percaya. Organisasi melibatkan penataan hubungan dan pengembangan proses kerja kolaboratif dari para pihak (baik itu internal atau ekternal) yang paling bekerja bersama (Chisthoper et al, 2016). Menurut Chisthoper et al (2016), pentaan hubungan dengan partner atau kemitraan tersebut secara alami akan membentuk sebuah perjanjian yang mengikat keduanya pada peran dan tanggungjawab masing masing pihak untuk mengembangkan program yang disepakati.

Philip et al (2014), menyimpulkan alasan utama organisasi menjalankan hubungan kemitraan dengan klien adalah peningkatan pendapatan, pengurangan biaya/resiko, transfer dan penggunaan pengetahuan secara inovasi. Namun pada implementasinya kemitraan dari beberapa pihak dapat menjadi sebuah masalah atau kesempatan untuk organisasi (Christhoper et al, 2016). Adderley dan Mellor (2014), menyatakan bahwa masing masing pihak memiliki agenda dan kepentingan yang berbeda, yang secara alami terkadang motivasi tersebut dapat melahirkan konfilk dalam hubungan kemitraan. Dalam sektor keuangan permasalahan yang sering timbul adalah tidak adanya komitmen untuk saling mempertahankan dan melaksanakan akad yang sudah dijanjikan, yang berakibat investasi tidak produktif, penyelewangan tanggung jawab, terjadi gagal bayar oleh anggota berakibat tingkat kolektibilitas pembiayaan bermasalah, non performing financing (NPF) tinggi. Oleh karena itu. Sangat perlu untuk dilakukan penyeleksian yang mamadai terhadap anggota pembiayaan.

Mengimplementasikan proses pemilihan mitra/anggota pembiayaan adalah cara yang efektif untuk mendefinisikan dan mengembangkan basis anggota yang baik. Dalam upaya untuk memastikan pekerjaan dan keuntungan yang cukup, banyak organisasi/lembaga menerima klien/mitra tanpa menentukan apakah mereka memenuhi kebutuhan dan harapan organisasi/lembaga atau tidak. Menurut Sandra J Boyer (2003), proses pemilihan anggota kerja penting karena dapat membantu mempertahankan atau meningkatkan profitabilitas organisasi/lembaga.

Copyright @ 2019, El-Ecosy: Jurnal Ekonomi dan Keuangan Islam

Fakultas Ekonomi dan Bisnis Islam Universitas Suryakancana 
Melalui proses ini organsisasi/lembaga dapat membantu memastikan bahwa ia bekerja dengan mitra/anggota yang bersedia dan layak untuk mempertahankan keberlanjutan lembaganya. Dampak dari pembatasan aktivitas sosial dari pademi covid 19, mengakibatkan banyak dari usaha anggota yang mengalami gangguan bahkan kebangkrutan, meskipun rata rata UMKM dengan elastisitas usahanya mampu untuk segera berubah, tidak seperti usaha besar yang rigiditas dan cukup kompleks. Akan tetapi perubahan itu belum tentu dapat direspon dengan cepat oleh pasar, sehingga memerlukan waktu untuk dapat memepertahankan cashflow para UMKM. Sehingga manfaat strategi pemelihan anggota pembiayaan (Selective lending) pada saat pademi covid 19, menjadi pendekatan untuk menselaraskan produktifitas dan resiko lembaga. anggota yang diinginkan adalah mitra/anggota onboarded. hal ini akhirnya mengarah pada pengurangan paparan resiko pelanggaran peraturan dan kegiatan ilegal (K Gowin, 2016).

Penyeleksian penyaluran pembiayaan ini menetukan keberlanjutan BMT ke depannya. Meskipun penyeleksian yang ketat akan mengurangi tingkat penambahan anggota, terutama anggota yang mengajukan pembiayaan. Pada penelitian ini, lebih menekankan variabel pemilihan anggota pembiayaan akan memberikan dampak yang baik untuk keberlanjutan BMT ke depannya.

Chisthoper et al (2016), menyatakan bahwa keberlanjutan dan pengembangan suatu organisasi dalam mencapai keunggulan yang kompetitif salah satunya adalah melalui kemitraan dan kolaborasi dengan pihak lain. Bisnis yang sustainable dapat dicapai melalui kemitraan namun harus memiliki keselarasan motivasi dan visi misi supaya tidak terjadi kendala dimasa yang akan depan (Adderley dan Mellor, 2014).

Mellor (2010), menambahkan bahwa adanya seleksi terhadap calon klien atau mitra dapat memengaruhi tingkat kepercayaan, kesempatan dan komitmen untuk mau menjalankan hak dan kewajiban secara adil dan penuh kesadaran. Berdasarkan diskusi diatas maka model yang terbentuk bahwa dalam 
keberlanjutan BMT dalam pademi covid 19 dapat dilakukan dengan pendekatan bisnis model dan pemilih pelayanan anggota pembiayaan (selective lending).

\section{Analisis Regresi Berganda}

a. Analisis regresi berganda bertujuan untuk mengetahui ada atau tidaknya pengaruh dua atau lebih variabel bebas $(\mathrm{X})$ terhadap variabel terikat $(\mathrm{Y})$;

b. Uji t bertujuan untuk mengetahui ada atau tidaknya pengaruh parsial (sendiri) yang diberikan variabel bebas $(\mathrm{X})$ terhadap variabel terikat $(\mathrm{Y})$;

c. Uji f bertujuan untuk mengetahui ada atau tidaknya pengaruh simultan (bersama-sama yang diberikan variabel bebas $(\mathrm{X})$ terhadap variabel terikat (Y);

d. Koefisien determinasi berfungsi untuk mengetahui berapa persen pengaruh yang diberikan variabel bebas $(\mathrm{X})$ terhadap variabel terikat $(\mathrm{Y})$.

Dalam penelitian ini:

$$
\begin{aligned}
& \mathrm{X}_{1}=\text { Model Bisnis } \\
& \mathrm{X}_{2}=\text { Selective Lending } \\
& \mathrm{Y}=\text { Sustainability BMT }
\end{aligned}
$$

\section{Tabel 1}

\begin{tabular}{|c|c|c|c|c|c|c|}
\hline \multirow{2}{*}{\multicolumn{2}{|c|}{ Model }} & \multicolumn{2}{|c|}{ Unstandardized Coefficients } & \multirow{2}{*}{$\begin{array}{c}\begin{array}{c}\text { Standardized } \\
\text { Coefficients }\end{array} \\
\text { Beta }\end{array}$} & \multirow[b]{2}{*}{$\mathrm{T}$} & \multirow[b]{2}{*}{ Sig. } \\
\hline & & $\mathrm{B}$ & Std. Error & & & \\
\hline \multirow[t]{3}{*}{1} & (Constant) & 4,663 & 3,924 & & 1,188 & ,260 \\
\hline & MODEL BISNIS (X1) &, 109 & ,205 & , 185 &, 532 & ,605 \\
\hline & $\begin{array}{l}\text { SELECTIVE LENDING } \\
\text { (X2) }\end{array}$ & ,043 & ,239 & ,063 & , 181 &, 860 \\
\hline
\end{tabular}

Uji Regresi Berganda

Coefficients $^{\mathrm{a}}$

a. Dependent Variable: SUSTAINABILITY (Y)

Berdasarkan analisis data dengan menggunakan SPSS 20, maka diperoleh hasil persamaan regresi sebagai berikut:

$$
\mathrm{Y}=4,663+0,109 \mathrm{X} 1+0,043 \mathrm{X} 2+\mathrm{e}
$$

Persamaan regresi di atas memperlihatkan hubungan antara variabel independent dengan varibel dependent secara parsial, dari persamaan tersebut dapat diambil kesimpulan bahwa: 
a. Nilai constanta adalah 4,663, artinya jika terjadi perubahan variabel model bisnis dan selective lending (nilai $\mathrm{X}_{1}$ dan $\mathrm{X}_{2}$ adalah 0) maka sustainability BMT ada sebesar 4,663 satuan;

b. Nilai koefisien regresi model bisnis adalah 0,109 , artinya jika variabel model bisnis $\left(\mathrm{X}_{1}\right)$ meningkat sebesar $1 \%$ dengan asumsi variabel selective lending $\left(\mathrm{X}_{2}\right)$ dan konstanta (a) adalah nol (0), maka sustainability BMT meningkat sebesar 0,109. Hal tersebut menunjukkan bahwa variabel model bisnis berkontribusi positif bagi sustainability BMT;

c. Nilai koefisien regresi selective lending adalah 0,043, artinya jika variabel selective lending $\left(\mathrm{X}_{2}\right)$ meningkat sebesar $1 \%$ dengan asumsi variabel model bisnis $\left(\mathrm{X}_{1}\right)$ dan konstanta (a) adalah nol (0), maka sustainability BMT meningkat sebesar 0,043. Hal tersebut menunjukkan bahwa selective lending yang memberikan berkontribusi positif bagi sustainability BMT.

\section{1) Uji t dan Uji F}

Perumusan Hipotesis
a) $\mathrm{H} 1=$ terdapat pengaruh model bisnis $\left(\mathrm{X}_{1}\right)$ terhadap sustainability (Y)
b) $\mathrm{H}_{2}=$ terdapat pengaruh selective lending $\left(\mathrm{X}_{2}\right)$ terhadap sustainability (Y)
c) $\mathrm{H}_{3}=$ terdapat pengaruh model bisnis $\left(\mathrm{X}_{1}\right)$ dan selective lending $\left(\mathrm{X}_{2}\right)$ secara simultan terhadap sustainability $(\mathrm{y})$
d) Tingkat kepercayaan $95 \%, \alpha=0,05$
e) Dasar Pengambilan Keputusan

\section{A) Uji t}
a) Jika nilai sig $<0,05$, atau $t_{\text {hitung }}>\mathrm{t}$ tabel maka terdapat pengaruh variabel $\mathrm{X}$ terhadap $\mathrm{Y}$.
b) Jika nilai sig $>0,05$, atau $t_{\text {hitung }}<t$
c) tabel maka tidak terdapat pengaruh variabel $\mathrm{X}$ terhadap variabel $Y$.
d) $\mathrm{T}$ tabel $=\mathrm{t}(\alpha / 2 ; \mathrm{n}-\mathrm{k}-1)=\mathrm{t}(0,05 / 2 ; 14-2-1)=\mathrm{t}(0,025 ; 11)$ $=2,201$


B) Uji F

a) Jika nilai sig $<0,05$, atau $F_{\text {hitung }}>F_{\text {tabel }}$ maka terdapat pengaruh variabel $\mathrm{X}$ secara simultan terhadap variabel $\mathrm{Y}$

b) Jika nilai sig $>0,05$, atau $\mathrm{F}$ hitung $<\mathrm{F}_{\text {tabel }}$ maka tidak terdapat pengaruh variabel $\mathrm{X}$ secara simultan terhadap variabel $\mathrm{Y}$.

c) $\quad \mathrm{F}_{\text {tabel }}=\mathrm{F}(\mathrm{k} ; \mathrm{n}-\mathrm{k})=\mathrm{F}(2 ; 12)=3,89$

Tabel 2

PENGUJIAN HIPOTESIS H $\mathrm{H}_{1}$ DAN $\mathrm{H}_{2}$ DENGAN UJI t Coefficients $^{\mathrm{a}}$

\begin{tabular}{|c|c|c|c|c|c|c|}
\hline \multirow[b]{2}{*}{ Mod } & & \multicolumn{2}{|c|}{ Unstandardized Coefficients } & $\begin{array}{l}\text { Standardized } \\
\text { Coefficients }\end{array}$ & \multirow[b]{2}{*}{$\mathrm{T}$} & \multirow[b]{2}{*}{ Sig. } \\
\hline & & B & Std. Error & Beta & & \\
\hline \multirow[t]{3}{*}{1} & (Constant) & 4,663 & 3,924 & & 1,188 & ,260 \\
\hline & MODEL BISNIS (X1) & 109 & ,205 & , 185 &, 532 &, 605 \\
\hline & $\begin{array}{l}\text { SELECTIVE } \\
\text { LENDING (X2) }\end{array}$ & ,043 & ,239 & ,063 & ,181 & ,860 \\
\hline
\end{tabular}

a. Dependent Variable: SUISTAINABILITY (Y)

\section{a. Pengujian Hipotesis Pertama $\left(\mathrm{H}_{1}\right)$}

Diketahui nilai sig. Untuk pengaruh $\mathrm{X}_{1}$ terhadap $\mathrm{Y}$ adalah sebesar 0,605> 0,05 dan nilai $t_{\text {hitung }} 0,532<\mathrm{t}$ tabel 2.201 , sehingga dapat disimpulkan bahwa $\mathrm{H}_{1}$ ditolak yang berarti tidak terdapat pengaruh $\mathrm{X}_{1}$ terhadap $\mathrm{Y}$.

\section{b. Pengujian Hipotesis Kedua $\left(\mathbf{H}_{2}\right)$}

Diketahui nilai sig untuk pengaruh $\mathrm{X}_{2}$ terhadap $\mathrm{Y}$ adalah sebesar 0,860 >

0,05 dan nilai $t_{\text {hitung }} 0,181<t_{\text {tabel }} 2,201$, sehingga dapat disimpulkan bahwa $\mathrm{H}_{2}$ ditolak yang berarti terdapat tidak terdapat pengaruh $\mathrm{X}_{2}$ terhadap Y.

Tabel 3

PENGUJIAN HIPOTESIS H3 DENGAN UJI F

\begin{tabular}{|ll|r|r|r|r|r|}
\hline Model & & Sum of Squares & \multicolumn{1}{|c|}{ Df } & Mean Square & \multicolumn{1}{c|}{ F } & \multicolumn{1}{c|}{ Sig. } \\
\hline 1 & Regression &, 800 & 2 &, 400 &, 295 &, $750^{\mathrm{b}}$ \\
& Residual & 14,915 & 11 & 1,356 & & \\
& Total & 15,714 & 13 & & & \\
\hline
\end{tabular}

a. Dependent Variable: SUISTAINABILITY (Y)

b. Predictors: (Constant), SELECTIVE LENDING (X2), MODEL BISNIS (X1)

\section{c. Pengujian Hipotesis Ketiga $\left(\mathbf{H}_{3}\right)$}

Berdasarkan output di atas diketahui nilai signifikansi untuk pengaruh $\mathrm{X}_{1}$ dan $\mathrm{X}_{2}$ secara simultan terhadap $\mathrm{Y}$ adalah sebesar 0,750 > 0,05 dan nilai 
$F_{\text {hitung }} 0,295<\mathrm{F}_{\text {tabel }} 3,89$, sehingga dapat disimpulkan bahwa $\mathrm{H}_{2}$ ditolak yang berarti tidak terdapat pengaruh $\mathrm{X}_{1}$ dan $\mathrm{X}_{2}$ secara simultan terhadap Y.

\section{Pengaruh penentuan model bisnis terhadap sustainability BMT}

Hasil penelitian dari anggota Gakopsyah BMT Jawa barat menunjukan bahwa model bisnis tidak berpengaruh terhadap sustainability BMT dalam pademi covid 19 tahun ini, sehingga dapat dinyatakan bahwa bisnis utama BMT sebagai lembaga intermediary layanan keuangan kepada anggota masih menjadi penopang utama operasional dan dapat mempertahankan profitabilitas BMT sehingga bisnis model diluar dari bisnis utama belum menjadi alternatif dan penopang operasional BMT.

Keberlanjutan BMT dengan model bisnis yang diluar bisnis utamanya, belum menjadi prioritas untuk BMT mitra Gakopsyah BMT Jawa Barat, dengan pendekatan Business Model Canvas sebagai blueprint untuk mempermudah mengkalkulasi semua proses dan resiko belum dioptimalkan, disebabkan proses perubahan altenatif bisnis dan pengukuran resiko kemampuan financial dan sumber daya manusia masih menjadi kendala dibeberapa BMT mitra Gakopsyah BMT Jawa Barat.

\section{Pengaruh pemilihan anggota pembiayaan (Selective Lending) terhadap sustainability BMT}

Hasil penelitian menunjukan bahwa pemilihan anggota pembiayan (selective lending) tidak terdapat pengaruh positif signifikan terhadap sustainability BMT. Adanya pemilihan anggota yang ketat dan selektif berdasarkan kondisi bisnis pada pademi covid 19 tidak berdampak pada peningkatan sustainability BMT di Anggota Gakopsyah BMT Jawa Barat. Suatu organisasi dapat berlanjut tidak terlepas dari anggotanya. Pemilihan anggota yang berkontibusi positif dan loyal dapat mempertahankan keberlanjutan BMT. Sehingga proses seleksi pemilihan anggota pembiayan dengan ketat dapat 
merugikan lembaga secara financial dan bisa mempengaruhi citra lembaga serta keberlanjutan lembaga.

Berdasarkan hasil penelitian yang terjadi di anggota Gakopsyah BMT Jawa barat pemilihan anggota pembiayaan (Selective lending) dengan cara menetukan bagiamana pemasaran akan menyesuikan prospek anggota baru untuk menselarakan dengan jumlah resiko mampu meningkatkan keberlanjutan BMT, pemilihan anggota pembiayaan yang ketat berdampak negatif untuk BMT. Ketatnya pemilihan anggota pembiayaan (Selective lending) menyebabkan berkurangnya jumlah anggota BMT. Sedangkan semakin berkurang anggota yang dimiliki BMT berdampak tidak dapat sustainability BMT dan berkurangnya profitabilitas BMT. Sekaligus dapat mengurangi perannya sebagai lembaga keuangan mikro untuk membantu para pengusaha mikro yang menjadi fokus utama layannnya.

\section{KESIMPULAN}

Berdasarkan hasil penelitian terkait dengan analisa keberlanjutan BMT dimasa pademi covid 19 berbasis kepada bisnis model dan pemilihan anggota pembiayaan (Selective lending) ada beberapa kesimpulan penting, pertama, BMT sebagai lembaga keungan mikro, berbadan hukum koperasi simpan pinjam dan pembiayan syariah (KSPPS) yang melayani para pengusaha mikro masih harus fokus kepada bisnis utamanya yaitu pelayanan keuangan baik pengumpulan simpanan anggota dan pembiayaan, baik kebutuhah modal usaha maupuan investasi, dan alternatif perubahan bisnis BMT belum dapat dilakukan sekaligus dikarenakan kendala financial, regulasi dan kemampuan sumber daya manusia. Kedua pemilihan anggota pembiayaan secara ketat memaksa BMT harus dapat menyeimbangkan antara peningkatan jumlah anggota dan resiko pengelolaan gagal bayar disebabkan dampak dari pademi covid 19. Meskipun implikasinya akan mengurangi jumlah anggota yang berdampak pada keberlanjutan BMT. Sedangkan kita ketahui semakin bertambah jumlah anggota mencerminkan eksistensi BMT dimasyarakat.

Copyright $(0)$ 2019, El-Ecosy: Jurnal Ekonomi dan Keuangan Islam

Fakultas Ekonomi dan Bisnis Islam Universitas Suryakancana 
Implikasi yang dapat diterapkan pada operasional BMT adalah: a) Berkaitan dengan bisnis model, BMT perlu melakukan kajian mendalam berdasarkan analisa resiko yang diakibatkan oleh pademi covid 19 ini, untuk mencari alternatif bisnis model yang mempu untuk dapat mempertahakan eksistensi BMT di masyarakat dengan tetap perpegang pada Visi, Misi dan fokus utama pelayanan akses keuangan untuk kalangan mikro; b) Berkaitan dengan pemilihan anggota pembiayaan (selective lending) karena tidak terdapat pengaruh signifikan antara pemilihan anggota pembiayaan dengan keberlanjutan BMT, maka perlu dilakukan penyesuaian antara tujuan dan harapan BMT, pemilihan anggota pembiyaan perlu dilakukan dengan bijak disesuaikan dengan kondisi bisnis, operasional dan mempertahankan profitabilitas BMT.

\section{REFERENSI}

Aziz, (2006). Akutansi BMT, Jakarta Pinbuk Press

Ridwan Muhamad. 2014. Manajemen Baitul Maal wat Tamwil (BMT) UII Press Yogyakarta.

Umar, Husein, 2001. Strategic Management in Action. Konsep, Teori dan Taktik Menganalisis Manajemen Startegis Strategic Business Unit Berdasarkan Konsep Michael Porter, Fred $R$ David dan Wheelen Hunger, Jakarta, Gramedia Pustaka Utama, hlm 31.

Widiyanto bin Mislan Cokrohadisumarto dan Sari, Yuli Indah, BMT Teori dan Model Model Pengembangan BMT, Depok, Rajawali Press, hlm 141.

Novita Herawati, "Penerapan Bisnis Model Kanvas dalam penentuan rencana Manajemen Usaha Kedelai Edame Goremg”, Jurnal Agroteknologi Vol. 13, No. 1 (2019)

https://www.kompas.com/tren/read/2020/09/23/123000565/siap-siap-resesiekonomi-ini-dampak-dan-cara-mengatasinya-?page=all, diunduh pada Rabu, 4 Oktober 2020, Pukul. 11.19 WIB

https://ipqi.org/apakah-business-model-itu/, diunduh pada Rabu, 4 Oktober 2020, Pukul. 11.19 WIB

https://republika.co.id/berita/q8tnhn282/dampak-covid19-bagi-bmt-part1, diunduh pada Rabu, 4 Oktober 2020, Pukul. 11.19 WIB

https://republika.co.id/berita/ekonomi/syariah-ekonomi/15/03/10/nkzar3-

beberapa-kendala-kerap-dihadapi-bmt, diunduh pada Rabu, 4 Oktober 2020, Pukul. 11.19 WIB

Wawancara dengan Andri Sapari dan Deni Setia ,tanggal 27 Oktober 2020, Pengurus Puskopsyah BMT Jawa Barat, di Kantor BMT Mitra Sadaya Jl. Caringin No.42 Kelurahan Kopo Kecamatan Bojongloa Kaler Kota Bandung. Pukul .15.00 - 17.30 WIB 